\title{
グラフ理論による露頭構造と層序の数学的表現
}

\author{
河西 秀夫*
}

\section{Mathematical Models of Geological Structure of Outcrops and Stratigraphy Based on Graph Theory}

\author{
Hideo KASAI*
}

\begin{abstract}
The examination of method to describe mathematically geological information observed at outcrops is necessary to construct outcrops database. For the purpose, we propose the structure graph and the stratigraphic graph by using the graph theory and the binary relation, and examine their theoretical background. We suppose that the geological structures have no upturned layers, and that there are no cuttings by fault and no penetrations of igneous rocks. The outcrop structure as the contact relations among beds can be expressed in the terms of binary relation $x R y$ which means two beds $x$ and $y$ contact each other and $y$ overlain $x$. This relation is expressed as a labeled directed graph $G=(V, R)$, where $V$ is a set of beds observed at an outcrop. We call this graph the structure graph. The stratigraphic sequence is the sedimentary order of beds, and this sequence is expressed in terms of binary relation $x U^{*} y$, which means $x$ is older than $y$. Symbol $U^{*}$ is a reflexive and transitive closure of the binary relation $x R y$, and the graph $S=\left(V, U^{*}\right)$ is called a strtigraphic graph. By this technique, we can make clear difference between outcrop structure and outcrop stratigraphic sequence mathematically. The stratigraphic sequence observed at an outcrop is a partial ordering and it may not necessarily be total ordering. The work to construct the local stratigrphic sequence of a certain area from structure observed at plural outcrops is formulated as the operation of the outcrop stratigraphic graphs. Thus we can mathematically express the geological structure and the stratigraphic sequence.
\end{abstract}

Key words : Graph theory, Structure graph, Directed graph, Stratigraphic sequence, Outcrop

\section{1. はじめに}

著者は露頭データベースの設計にあたり，露頭データの 記述方法としてグラフを使用した方法を提案し，さらに， グラフを行列で表現した構造行列，式で表現した層序式も 提案した（河西，2003；河西，2005；Kasai, 2009）。これら の表現方法を導入すると, 露頭で観察される地質構造と層 序が数学的に表現できた.

露頭データの記述方法としてのグラフはラベル付き有向 グラフであり, 頂点のラベルは地層名, 弧のラベルは地層 間の接触関係である。このグラフを層序グラフあるいは構 造グラフとよんだ(河西, 2005; Kasai, 2009).また, 露頭デー 夕ベースに登録された露頭データから露頭データの演算に よりある範囲の地域の層序が得る方法も考察した. しかし, 露頭構造と層序の両方とも単層間の接触関係で表現してお り，両者の違いが明確ではなかった。また，グラフを使用 した表現方法では, 複数の露頭の層序からある範囲の地域
の層序を組み立てるための演算が複雑になり実用的ではな かった，本論文では，層序と露頭構造の数学的な理論を考 察して露頭構造と層序を数学的に再定義した．この再定義 をもとに，露頭構造を表現する構造グラフと層序を表現す る層序グラフに区分し，さらに露頭の層序データから地域 の層序を組み立てる方法を改めて考察した。本論文ではこ の結果について述べる。

\section{2. ラベル付きグラフの概要}

$V=\left\{v_{i} \mid 1 \leqq i \leqq n\right\}$ を集合, $A$ を $V$ 上の二項関係とする. $A$ は $V \times V$ の部分集合であり, $\left(v_{i}, v_{j}\right)$ が $A$ の元であることを, $v_{i} A v_{j}$ と表す. $n$ は元の数である.

有向グラフ $G$ は順序対 $(V, A)$ で抽象的に定義される. すなわち,

$$
G=(V, A)
$$

このとき, $V$ の要素を頂点という.グラフ $G$ の頂点の数 
を位数といい $|G|$ で表すＡの要素である順序対を孤とよ ぶ. 弧 $\left(v_{i}, v_{j}\right)$ は, 通常, $v_{i} v_{j}$ と略記される. 弧 $v_{i} v_{j}$ におい て， $v_{i}$ は弧 $v_{i} v_{j}$ の始点， $v_{j}$ は弧 $v_{i} v_{j}$ の終点とよばれる. 幾 何学的には, 有向グラフ $G$ は標識づけられた点の集合 $V$ と, 各 2 点の間にある矢印の集合 $A$ とで図示される. $v_{i} v_{j}$ は, 頂点 $v_{i}$ から頂点 $v_{j}$ への矢印である. 2 つの頂点が矢印で結 ばれているとき，2つの頂点は隣接しているという。この とき，頂点 $v_{i}$ 及び $v_{j}$ は弧 $v_{i} v_{j}$ または $v_{j} v_{i}$ に接続していると いう. 有向グラフ $G$ において頂点 $v_{i}$ から出る弧の数を出 次数といい, 頂点 $v_{i}$ 入入る弧の数を入次数という.

弧には方向性があるので, $v_{i} \neq v_{j}$ のとき $\left(v_{i}, v_{j}\right) \neq\left(v_{j}, v_{i}\right)$ すなわち $v_{i} v_{j} \neq v_{j} v_{i}$ である. 有向グラフ $G$ は頂点の集合 $V$ と弧の集合 $A$, 接続関数 $\phi_{G}$ を使用して次のようにも表さ れる。

$$
G=\left(V, A, \phi_{G}\right)
$$

接続関数 $\phi_{G}$ は頂点の順序対を弧に対応させる関数である. グラフは接続関数を省略し $G=(V, A)$ と略記される場合 もある。

なお，点の集合 $V$ と，各 2 点を結ぶ線分の集合 $E$ を図 示したグラフを無向グラフとよぶ. $E$ に属する線分は辺と よばれる。無向グラフの辺には方向性がない.

無向グラフ $G$ の部分グラフとは，その頂点がすべて $V$ に属し，その辺がすべて $E$ に属するグラフである。この 定義を有向グラフに応用して, 2 つ有向グラフ $G=(V, A)$ と $G^{\prime}=\left(V^{\prime}, A^{\prime}\right)$ について,$V^{\prime} \subseteq V$ かつ $A^{\prime} \subseteq A$ が成立する とき, $G^{\prime}$ は $G$ の部分グラフであるという.

任意の有向グラフ $G$ が与えられたとき，始点と終点が それぞれ同じである複数の弧が存在する場合，これらの弧 を多重弧という。また，始点と終点が同一の弧をループと いう.

任意の有向グラフ $G$ が与えられたとき， $G$ の歩道とは， $v_{1} v_{2}, v_{2} v_{3}, \cdots, v_{m-1} v_{m}$ の形をした孤の有限列（Wilson, 1996）ま たは $v_{1}, v_{1} v_{2}, v_{2}, v_{2} v_{3}, v_{3}, \cdots, v_{m-1}, v_{m-1} v_{m}, v_{m}$ の形をした頂点と 弧の有限列 (Bondy and Murty, 2008) である。 $v_{i} v_{j}$ は頂点 $v_{i}$ と $v_{j}$ を連結する弧である。この列を $v_{1}$ から $v_{m}$ への歩道, または $v_{1}-v_{m}$ 歩道という。このとき， $v_{1}$ をその歩道の始 点とよび， $v_{m}$ をその歩道の終点とよぶ.すべての孤が異 なる歩道を小道とよぶ。さらに, すべての頂点が異なる 小道を道とよぶ．特に有向効グラフの道を有向道という。 頂点 $v_{i}$ と $v_{j}$ を連結する弧が 1 つしか存在しない場合は弧 を省略して道を頂点のみで表すこともある（恵羅・土屋， 2010). 以下， $v_{1}$ から $v_{m}$ への道 $P$ を頂点 $v_{i}$ のみを用いて

$$
P=\left(v_{1}, v_{2}, v_{3}, \cdots, v_{m-1}, v_{m}\right)
$$

または，必要に応じて頂点も孤も書きいれて，

$$
P=\left(v_{1}, v_{1} v_{2}, v_{2}, v_{2} v_{3} v_{3}, \cdots, v_{m-1}, v_{m-1} v_{m}, v_{m}\right)
$$

と書くことにする． $v_{i}$ を始点， $v_{j}$ を終点とする道を $v_{i}-v_{j}$ 道という。 $v_{i}-v_{j}$ 道の長さは道内の孤の数である. 始点と 終点が同じ頂点である道を閉路という。

有向グラフ $G$ の任意の頂点の間に道がある場合， $G$ は
連結であるといい, 連結でない場合は非連結であるという。 有向グラフ $G$ の任意の 2 頂点間に双方向の道が存在する ときは，Gは強連結であるといい， 1 方向の場合， $G$ は片 方向連結であるという。孤を持たない頂点だけのグラフを 空グラフという．頂点に接続する孤がないとき，その頂点 を孤立点という。

有向グラフ $G$ の弧を辺に置き換えたグラフを $G$ の基礎 グラフという，基礎グラフ（無向グラフ）における道は, 有向グラフの歩道・小道・道の定義に現れる孤を辺に置き 換えて同様に定義される.

第 1 図のグラフ $G=(V, A)$ の頂点の集合 $V$ と弧の集合 $A$ は次のようになる。

$$
\begin{aligned}
& V=\left\{v_{1}, v_{2}, v_{3}, v_{4}, v_{5}\right\} \\
& A=\left\{a_{1}, a_{2}, a_{3}, a_{4}, a_{5}, a_{6}, a_{7}\right\}
\end{aligned}
$$

第 1 図の有向グラフ $G$ の任意の頂点の間には道が存在 する。例えば，頂点 $v_{3}$ と $v_{1}$ の間には

$$
P=\left(v_{3}, a_{2}, v_{2}, a_{1}, v_{1}\right)
$$

で表される道が存在する. 頂点 $v_{1}$ と $v_{5}$ は弧 $a_{6}$ と $a_{7}$ の多重 弧で接続されており， $a_{4}$ はループである.グラフ $G$ はその 基礎グラフの任意の頂点の間に道があるので連結グラフで ある。

各頂点と弧にラベルが付いた有向グラフ $G$ をラベル付 き有向グラフといい, 次のように表される.

$$
G=\left(V, A, \phi_{V}, \phi_{A}\right)
$$

ここで， $\phi_{V}$ は頂点にラベルを対応づける写像であり， $\phi_{A}$ は弧にラベルを対応づける写像である.すなわち頂点 $v_{i}$ のラベルは $\phi_{V}\left(v_{i}\right)$ であり, 弧 $a_{j}$ のラベルは $\phi_{A}\left(a_{j}\right)$ である.

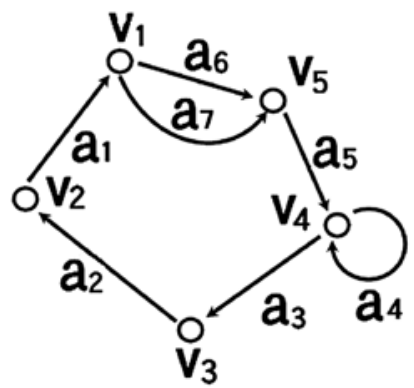

第 1 図 有向グラフ. 白丸が頂点, 矢印がついた線が弧, $v_{i}$ が頂点, $a_{i}$ が弧である．弧には向きがあり， $a_{1}$ は頂点 $v 2$ から $v_{1}$ へ 向く. $a_{6}$ と $a_{7}$ は多重弧であり， $a_{4}$ はループである.グラ フは閉路である。

\section{3. 層序と構造のグラフ表現}

\section{3-1. 議論の進め方}

露頭で観察される断面から地層の積み重なりの状況がわ かる．この積み重なりは地層の形成順序を示していること が多いが，地層の逆転がある場合，空間的に上位に位置す る地層は空間的に下位に位置する地層よりも形成順序が古 いことになる。また, 花崗岩と堆積岩が接触している場合, 花崗岩が新しい時期に貫入している可能性もある。このよ うに空間的に下位にあるものほど形成時期が古いとは限ら 
ない，本論文では，露頭で観察される地層の積み重なりの 状況を「露頭構造」あるいは単に「構造」とよぶことにする.

層序とは複数の地層の堆積順序あるいは形成順序であ る．地層の形成順序を確定するにあたって，地層の逆転が 存在しないところでは，下位に位置する地層ほど形成年代 は古いという地層累重の法則が適用できる。1枚の地層は ある瞬間に堆積したものではなく，地層の堆積開始から完 了まで一定の時間がかかる。つまり，地層の下部は上部よ り古いということになる。地層の堆積期間を考慮に入れる と地層の新旧関係の数学的取り扱いが困難になる. 塩野 （1997）は地層の積み重ねをカードの積み重ねに置き換え て層序の理論を考察した。これにならって, 本論文でも地 層の堆積に要する時間を考慮せず，地層を 1 枚の板として 地層単位の堆積順序のみを考える. 整合, 不整合, 断層, 貫入など地層間の接触関係は多様であり，それぞれは地質 構造発達史を考える上で重要な情報である。しかし, 論点 を明確にするために，本論文では地層の逆転がなく，断層 による切断や火成岩の貫入もない地層群だけで構成される 地質構造を対象として以下の議論を進める.

ある露頭で地層 $\mathrm{B}$ が地層 $\mathrm{A}$ を不整合で覆う場合, $\mathrm{A}$ の 堆積と B の堆積との間には隆起 $\rightarrow$ 侵食 $\rightarrow$ 沈降という長い 時間の経過がある。一方，地層 $\mathrm{A}$ の上に地層 $\mathrm{B}$ が整合で 接触している場合, Aに引き続いて B が堆積したといえる. この時間ギャップの有無は地層の形成史を考える上で重要 な情報となる。このように, 層序は堆積順序だけではなく, 地層間の接触関係も重要になる。したがって, 以下では形 成順序と接触関係の両者が確定したものを「層序」とよぶ ことにする。

ある地域に分布する単層の集合を $V$ とする．塩野 (1997) と同様に単層は一瞬に形成されると仮定し, 集合 $V$ の任 意の単層 $x$ と $y$ について, $x$ が $y$ よりも形成時期が古いと いう関係を $x U \mathrm{y}$ と書き, このような関係にある順序対 $(x$, $y)$ の集合を $U$ と書く.このような単層の新旧関係は次の 性質をもつとして以下の議論を進める.

反射律：すべての $x \in U$ に対して， $x U x$

反対称律：すべての $x, y \in U$ に対して, $x U y \wedge y U x \Rightarrow x=y$ 推移律：すべての $x, y, z \in U$ に対して, $x U y \wedge y U z \Rightarrow x U z$ すなわち, $V$ 上の関係 $U$ は半順序である. $(V, U)$ は半順序 集合であり， $(V, U)$ は単層の堆積順序を表すことになる.

半順序集合 $(V, U)$ の任意の 2 つの元が比較可能な場合, つまり

比較可能律：すべての $x, y \in U$ に対して, $x U y \vee y U x$ が成立する場合，Uは全順序となる。

一般に半順序集合 $(V, U)$ の各元に対して, $V$ 上の順序 $U$ を保存するように自然数を割り当てることができる。す なわち, $V$ の任意の元 $x$ と $y$ に対して $, x=v_{i}, y=v_{j}$ とし たとき

$$
v_{i} U v_{j} \Rightarrow i \leqq j
$$

となるように番号付けることができて $, v_{1}, v_{2}, \cdots, v_{n}$ のよう
に並べることができる．ただし，Uが全順序でない場合に

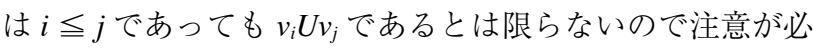
要である。

本論文では, 露頭で観察される層序を「露頭層序」とよび, ある一定の範囲の地域における層序を「地域層序」とよぶ ことにする。地域層序はある地域に存在するすべての地層 の堆積順序と地層間の接触関係が確定したものである.

露頭にはその地域に存在する地層のいくつかが露出して いるので，露頭層序は地域層序の部分グラフである．ある 地域に存在する地層の集合を

$$
V=\{a, b, c, d\}
$$

としたとき，Vの部分集合をあげると次のようになる．

\{\}$,\{a\},\{b\},\{c\},\{d\},\{a, b\},\{a, c\},\{a, d\},\{b, c\},\{b, d\}$, $\{c, d\},\{a, b, c\},\{a, b, d\},\{a, c, d\},\{b, c, d\},\{a, b, c, d\}$

各露頭でみられる地層の組み合わせはこのいずれかであ る. $\{a\},\{b\},\{c\},\{d\}$ はそれぞれ 1 つの地層からなる露 頭を意味する．空集合＼{＼}は露頭が植生などに覆われてど の地層も観察できない場合に相当する。 $\{a, b, c, d\}$ はす心゙ ての地層が露出している露頭である。露頭における地層の 積み重なりすなわち「露頭構造」を観察して，単層の形成 順序と接触関係を確定したものが「露頭層序」である．数 多くの露頭で得られた露頭層序を統合することにより，地 域全体の「地域層序」を確定することができる。このよう な地質調査の手順を念頭に置いて，本論文では

・露頭構造を表す方法

·露頭層序を表す方法

・地域層序を露頭層序から導く方法

をラベル付き有向グラフを基礎にして考察する。

\section{3-2. 構造グラフ}

\section{(a) 構造グラフの定義}

露頭で観察された岩石にその特徴から名前が付けられ る。また，これらの名前が付けられた岩石をまとめて地層 に区分し，これらの地層にも名前が付けられている。こ の名前付けは写像 $f: B \rightarrow F$ で表現できる（塩野・弘海原, 1991). B を観察された岩石とすると $F$ はその名前となり, $B$ を岩石の名前とすると $F$ は地層の名前になる．互いに接 触する地層 $x$ と $y$ の接触状態の名称は関数 $\phi_{A}$ を使用して $\phi_{A}(x, y)$ で表現できる. 本論文では地層の接触関係を整 合と不整合に限定しているので， $\phi_{A}$ は順序対 $(x, y)$ に接 触関係の名称の集合 $A=\{$ 整合，不整合 $\}$ の 1 つ元を対 応つける写像である．以下では，露頭で観察される岩石と 接触関係にはそれぞれ名称が付けられているものとする. また，この岩石名を地域全体で識別・対比が可能な地層の 最小単位であるとし，これを仮に「単層」よんで議論を進 める（最小単位を部層あるいは累層としても以下の議論の 本質は変わらない).

次のように $V, R, \phi_{V}, \phi_{A}$ で定義される有向グラフ $G=(V$, $\left.R, \phi_{V}, \phi_{A}\right)$ を「構造グラフ」とよぶ. 
$1 つ の$ 露頭で識別された単層の集合を $V$ とする. 2 つの 単層 $x$ と $y$ が互いに接触していて， $x$ が空間的に下側にあ ることを $x R y$ と書き，このような関係にある順序対 $(x, y)$ の集合を $R$ と書く(河西, 2000 ; Kasai, 2009). $R$ は次のよ うになる。

$$
R=\{(x, y) \mid x R y, x, y \in V\}
$$

$\phi_{V}$ は $V$ の元である各単層に地層名を対応付ける写像で ある、 $x R y$ である $x$ と $y$ の接触関係の名称を $\phi_{A}(x, y)$ と書 く. $\phi_{A}$ は順序対 $(x, y)$ に接触関係の名称の集合 $A=$ 整合, 不整合\}の 1 つの元を対応つける写像 $\phi_{A}: R \rightarrow A$ である.

グラフの頂点 $x$ には単層名のラベル $\phi_{V}(x)$ が付けられ, 孤 $(x, y)$ には接触関係のラベル $\phi_{A}(x, y)$ が付けられるので, 構造グラフはラベル付き有向グラフになる．構造グラフは 弧の方向を下側の単層 $x$ から上側の方向に向くように描く. 弧の方向をグラフの下部から上部に向けるように描くと, グラフと露頭断面との対応が付けやすくなるからである.

第 2 図に構造グラフの例を示す. 各露頭断面の右側に対 応する構造グラフを示す。第 2 図 (a) と (b) の露頭断面は 3 つの単層 $x, y, z$ からなる. $x$ と $y$ は整合で接している。(a) の場合には $z$ が $x$ と $y$ を不整合で覆うが，(b)の場合には $z$ はのみを不整合に覆っている。露頭断面 (a)の場合, 単層の集合 $V$ は $\{x, y, z\}$ であり，接触関係 $R$ は

$$
x R y, x R z, y R z
$$

である。ラベルは

$$
\begin{aligned}
& \phi_{A}(x, y)=\text { 整合 } \\
& \phi_{A}(x, z)=\text { 不整合 } \\
& \phi_{A}(y, z)=\text { 不整合 }
\end{aligned}
$$

になる，
一方, 露頭断面 (b) の場合, 単層の集合 $V$ は露頭断面 (a) と同じく, $V=\{x, y, z\}$ であるが，接触関係 $R$ は

$$
x R y, y R z
$$

となり，ラベルは

$$
\begin{aligned}
& \phi_{A}(x, y)=\text { 整合 } \\
& \phi_{A}(y, z)=\text { 不整合 }
\end{aligned}
$$

となる。

第 2 図 (c) と (d) の露頭断面は 5 つの単層 $v, w, x, y, z$ か らなる。 $v$ が空間的に最下位の単層, $z$ が空間的に最上位 の単層である．断面 (c)では整合関係にある 3 つの単層 $w$, $x, y$ はを不整合で覆い, またそれぞれは $z$ に不整合で覆 われている，断面 $(\mathrm{d})$ では単層 $w$ が $v$ を整合で覆い, 単層 $x$ が $w$ を不整合で覆い, 単層 $y$ は $x$ を不整合で覆う。単層 $z$ は単層 $y, x, w$ を不整合で覆う。

露頭断面 $(\mathrm{c})$ と $(\mathrm{d})$ に露出する単層の集合はともに $V=\{v$, $w, x, y, z\}$ である。露頭断面 (c) の接触関係 $R$ は次のよう になる。

$v R w, v R x, w R x, w R z, x R z, x R y$

露頭断面 $(\mathrm{d})$ の接触関係 $R$ は次のようになる.

$v R w, w R x, w R z, x R y, x R z, y R z$

露頭断面 (e) では単層 $y$ が $w$ と $x$ を不整合に覆い, $z$ が $y$ を整合で覆っている， $w$ と $x$ は接していない。単層の集 合は $V=\{w, x, y, z\}$ であり, 接触関係 $R$ は次のようになる. $w R y, x R y, y R z$

露頭断面 $(\mathrm{f})$ では単層 $y$ と $z$ が $x$ を不整合に覆っている. $y$ と $z$ は接していない. 単層の集合は $V=\{x, y, z\}$ であり, 接触関係 $R$ は次のようになる。

$x R y, x R z$
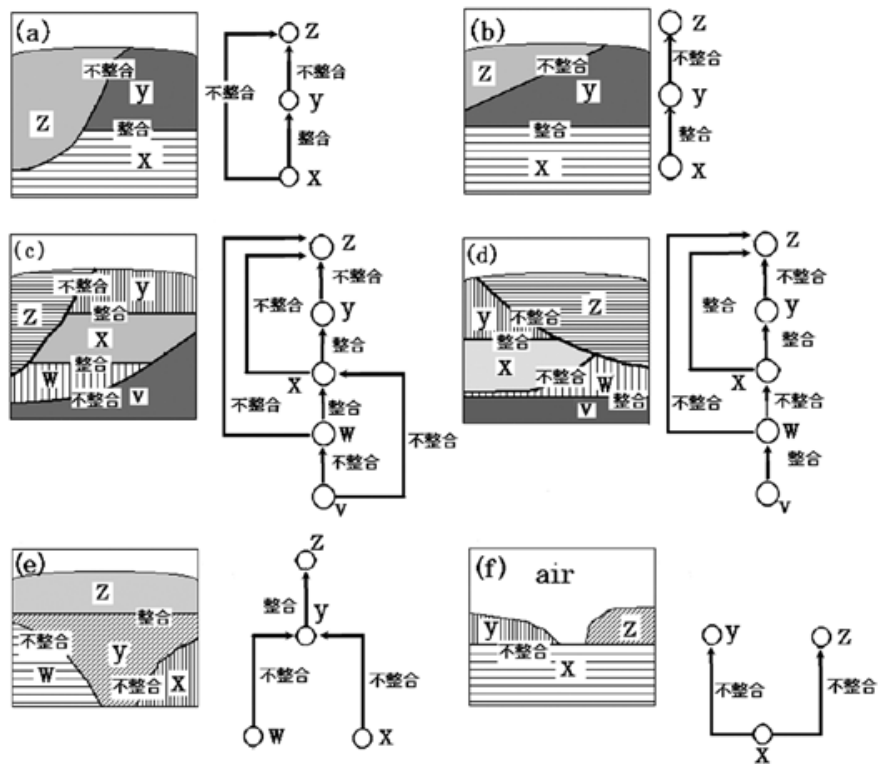

第 2 図 構造グラフの例．各露頭の層序グラフを右側に示す．頂点は単層，矢印は単層間の空間的な位置関係を表し，下側の単層から 上側の単層に向く．露頭断面 (a) と (b)，(f) は 3 つの単層 $x, y, z$ からなり，露頭断面 (c) と (d) は 5 つの単層 $v, w, x, y, z$ からな る. 露頭断面 (e) は 4 つの単層 $w, x, y, z$ からなる. (a), (b), (f) では $x$ が空間的に最下位の単層で, (a) と (b) は $z$ が空間的に最上

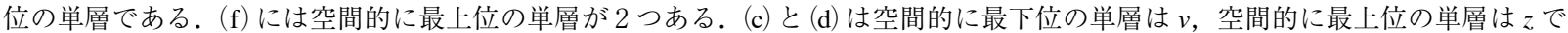

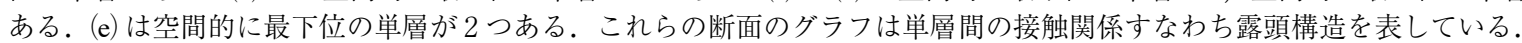


第 2 図 (a) の構造グラフでは単層 $x$ に対応する頂点の出 次数が 2 である。これは, 単層 $x$ が $y$ と $z$ の両方に覆われ ていることを意味している. (b) の例では単層 $x$ と $y$ に対 応する頂点の出次数がそれぞれ 1 である。これは, 各単層 を覆う単層が1つしかないことを意味している.(c)の例 では, 単層 $v, w, x$ に対応する頂点の出次数は 2 以上である. これは, 単層 $v, w, x$ はそれぞれ複数の単層で覆われてい ることを意味している．単層 $z$ に対応する頂点の入次数は 3 であるが, これは単層 $z$ が 3 つの単層を覆っていること を表している。

\section{(b) 構造グラフの性質}

構造グラフは露頭の構造を表すラベル付き有向グラフで あり，頂点と弧はそれぞれ単層と単層間の接触関係を表し ている，第 2 図に例示したように，構造グラフによって露 頭断面における単層の空間的上下関係と単層間の接触関係 すなわち構造が正確に表現できる。

構造グラフの性質は次の通りである（河西, 2003; Kasai, 2009).

(1) 構造グラフ $G$ の位数は 1 以上，すなわち $|G| \geqq 1$ であ る. 位数が1のグラフは孤立点からなる空グラフであり, 1つの単層からなる露頭を意味している。

(2) 構造グラフで 2 点が連結している場合は必ず片方向連 結である、構造グラフの弧は空間的に下位の地層から空 間的に上位の地層に向く。このため,片方向連結となる.

(3) 構造グラフにおける頂点の出次数は, その頂点に対応 する単層が接触している空間的に上位の単層の数を表し ている. また, 頂点の入次数は, その頂点に対応する単 層が接触している空間的に下位の単層の数を表している.

(4) 構造グラフにおいて, 出次数が 0 の頂点がただひとつ 存在するとき, その頂点は空間的に最上位の単層を表し, 入次数が 0 の頂点がただひとつ存在するとき，その頂点 は空間的に最下位の単層を表す。

（5）構造グラフでは，多重弧が存在しない。弧は地層間の 接触関係を意味しており, 接触関係は“整合”あるいは“不 整合”のいずれか 1 種類しかないからである.

\section{3-3. 層序グラフ}

\section{(a) 層序グラフの定義}

構造グラフ $G=\left(V, R, \phi_{V}, \phi_{A}\right)$ は露頭における単層の空 間配置や接触関係を記述した観察データの図式表現であ る。つまり露頭の構造を表したものである。このままでは 地層の形成順序とは直接結びつかない. 例えば,第 2 図 (a) (b) の露頭断面の場合，単層 $x$ と $y$ に地層の逆転がない場 合は $x$ が $y$ より形成時期が古いことになるが，逆転が存在 する場合は $y$ が $x$ より古いことになる。地層の形成順序を 議論するには，露頭における単層の空間配置や接触関係の 観察結果に地層累重の法則などを当てはめて，地層の新旧 関係に変換するという地質学的処理を行なう必要がある. この処理を行なった結果が層序グラフである.
以下のように定義される集合 $V$ 上の関係 $U^{*}$ で定義され るラベル付き有向グラフ $S=\left(V, U^{*}, \phi_{V}, \phi_{A}\right)$ を「層序グラフ」 という。.ここで， $\phi_{V}$ は $V$ の元である各単層に地層名を対 応付ける写像であり, 構造グラフにおける $\phi_{V}$ と同じであ る. $\phi_{A}$ は弧に接触関係を表すラベルを対応づける写像で あり，構造グラフにおける $\phi_{V}$ と基本的には同じであるが， 弧が追加されるので，それらに新たな名称がつけられるこ とがある。

露頭で観察される単層間の層序を対象とする場合, 露頭 の層序を表すという意味で特に「露頭層序グラフ」とよぶ ことにする。

露頭断面で観察される単層の集合を $V$ とする，集合 $V$ の元である単層 $x$ と $y$ が接触しており, $x$ が $y$ より形成時 期が古いとき，この関係を $x U y$ とかく．関係 $U$ の集合は 次のようになる。

$$
U=\{(x, y) \mid x U y, x, y \in V\}
$$

以下の議論では, $x \neq y$ のとき $x U y$ と $y U x$ が同時に成り立 つことはない，つまり，Uは反対称的な関係であるとする.

関係 $U$ の推移的閉包を $U^{+}$とする. 集合 $V$ の要素が有限 個の場合，推移的閉包 $U^{+}$は次のように定義される.

$$
U^{+}=U^{1} \cup U^{2} \cup \cdots \cup U^{n}
$$

ここで, $n$ は $V$ の元の数, すなわち $n=|V|$ である. $U^{k}$ は $U$ 自身を $k$ 回合成することを意味する。 $U^{1}=U$ である. 推移的閉包 $U^{+}$は次の推移律を満たす.

$$
\text { すべての } x, y, z \in V \text { に対して } x U^{+} y \wedge y U^{+} z \Rightarrow x U^{+} z
$$

$U$ の推移的閉包 $U^{+}$に反射的性質を追加した関係 (反射 的かつ推移的閉包) を $U^{*}$ とする。この $U^{*}$ は

反射律：すべての $x \in U$ に対して， $x U^{*} x$

反対称律：すべての $x, y \in U$ に対して,

$$
x U^{*} y \wedge y U^{*} x \Rightarrow x=y
$$

推移律：すべての $x, y, z \in U$ に対して,

$$
x U^{*} y \wedge y U^{*} x \Rightarrow x U^{*} z
$$

を満たすので, $V$ 上の半順序である.したがって, $V$ の各 元を

$$
v_{i} U^{*} v_{j} \Rightarrow i \leqq j
$$

となるように， $v_{1}, v_{2}, \cdots, v_{n}$ のように番号付けることがで

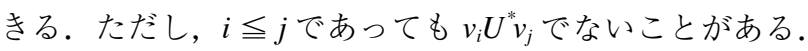
$U^{*}$ が全順序になる場合に限り， $i \leqq j$ であれば $v_{i} U^{*} v_{j}$ であ るといえる。この場合， $\left(v_{1}, v_{2}, \cdots, v_{n}\right)$ は地層の形成順序を 表している.

層序グラフ $S=\left(V, U^{*}, \phi_{V}, \phi_{A}\right)$ における $\phi_{V}$ は構造グラ フの場合と同じく，Vの元に地層名を対応付ける写像であ る. $\phi_{A}$ は構造グラフの場合と同じく, 順序対 $(x, y)$ に接 触関係の名称を対応付ける写像であるが，推移的閉包によ り追加された弧のラベルとしては一律に“推論”の用語を 使用する．自明な反射的性質を表すループには特にラベル はつけない.

第 3 図は第 2 図と同じ露頭断面から導かれた層序グラフ である。上側に露頭断面，下側に層序グラフを示す. 
第 3 図 (a) の露頭断面は第 2 図 (a) と同じものである. この露頭は 3 つの単層 $x, y, z$ からなるが, 地層の逆転がな いと仮定すると，地層累重の法則により，

$$
\begin{aligned}
& x R y \Rightarrow x U y \\
& x R z \Rightarrow x U z \\
& y R z \Rightarrow y U z
\end{aligned}
$$

と推論できる. 第 3 図 $\left(\mathrm{a}^{\prime}\right)$ の層序グラフは第 2 図 (a) の構造 グラフに反射的性質を示すループを加えたものである. $U^{*}$ は半順序であり $, x=v_{1}, y=v_{2}, z=v_{3}$ と番号をつけること により， $v_{i} U^{*} v_{j} \Rightarrow i \leqq j$ となるように，すなわち形成時期の 古いものから新しいものに向かって, 番号をつけることが できる。この場合，3つの単層の間に比較可能律が成立す るので全順序となる。したがって, 次の 3 つの単層の並び

$$
P=\left(v_{1}, v_{2}, v_{3}\right)=(x, y, z)
$$

は単層の堆積順序となる。 $x$ が最も古い単層, $z$ が最も新 しい単層である。

$P$ は $v_{1}-v_{3}$ 道と同じ表記なので，頂点を連結する弧 $v_{i} v_{j}$ を 記入すると次のようになる。

$$
P=\left(v_{1}, v_{1} v_{2}, v_{2}, v_{2} v_{3}, v_{3}\right)
$$

$P$ の弧 $v_{i} v_{j}$ の位置に, 弧 $v_{i} v_{j}$ のラベル (接触関係の名称) $\phi_{A}\left(v_{i}\right.$, $\left.v_{j}\right)$ を代入した

$P^{\prime}=\left(v_{1}\right.$, 整合, $v_{2}$, 不整合, $\left.v_{3}\right)=(x$, 整合, $y$, 不整合, $z)$ は単層の形成順序と単層間の接触関係を表しているので, 「層序」である。

第 3 図 (b) の露頭断面は 3 つの単層 $x, y, z$ からなる. 地 層の逆転がないと仮定すると, 地層累重の法則により,

$$
\begin{aligned}
& x R y \Rightarrow x U y \\
& y R z \Rightarrow y U z
\end{aligned}
$$

と推論できる. 単層 $x$ と $z$ は直接接触していないが, 関係 $U$ の推移的閉包から

$$
x U^{*} y \wedge y U^{*} z \Rightarrow x U^{*} z
$$

が推論できる。第 3 図 $\left(\mathrm{b}^{\prime}\right)$ の層序グラフは第 2 図 $\left(\mathrm{b}^{\prime}\right)$ の 構造グラフに反射的性質を示すループと推移的閉包で生 み出された関係 $x U^{*} z$ を表す弧 $(x, z)$ を加えたものである. 追加された弧 $(x, z)$ には“推論”というラベルが付けられ ている。第 3 図 (a) の場合と同様に, $U^{*}$ は半順序となり, $v_{i} U^{*} v_{j} \Rightarrow i \leqq j$ となるように，形成時期の古いものから新 しいものに向かって $x=v_{1}, y=v_{2}, z=v_{3}$ と番号をつける ことができる.この場合も 3 つの単層の間に比較可能律が 成立するので全順序となる。したがって, 次の 3 つの単層 の並び

$$
P=\left(v_{1}, v_{2}, v_{3}\right)=(x, y, z)
$$

は単層の堆積順序となる。 $x$ が最も古い単層, $z$ が最も新 しい単層である。 $P$ は $v_{1}-v_{3}$ 道と同じ表記なので, 頂点 を連結する弧 $v_{i} v_{j}$ を記入すると次のようになる.

$$
P=\left(v_{1}, v_{1} v_{2}, v_{2}, v_{2} v_{3}, v_{3}\right)
$$

$P$ の弧 $v_{i} v_{j}$ の位置に, 弧 $v_{i} v_{j}$ のラベル（接触関係の名称）を 代入した

$P^{\prime}=\left(v_{1}\right.$, 整合, $v_{2}$, 不整合, $\left.v_{3}\right)=(x$, 整合, $y$, 不整合, $z)$ は単層の形成順序と単層間の関係を表しているので，「層 序」である。

第 3 図 (c)では，第 2 図 (c) の構造グラフに反射的性質を 示すループと推移的閉包で生み出された関係を示す弧 $(v$, $y ）$ と $(w, y)$ が追加されており，(d) では反射的性質を示す ループと推移的閉包を示す弧 $(v, y),(v, x),(v, z),(w, y)$ がそれぞれ追加されている。(e)では反射的性質を示すルー

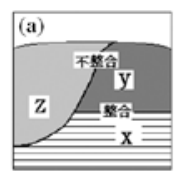

(a')
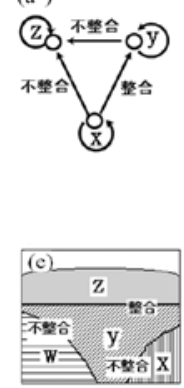

$\left(\mathrm{c}^{\prime}\right)$

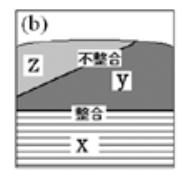

(b')
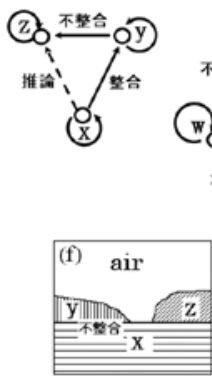

(f')
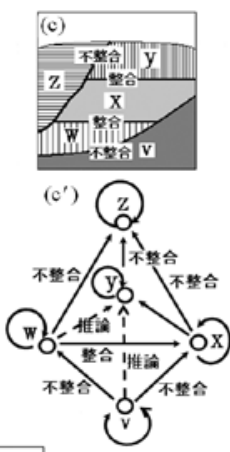
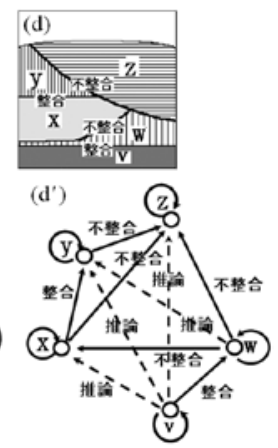

$\left(d^{\prime}\right)$
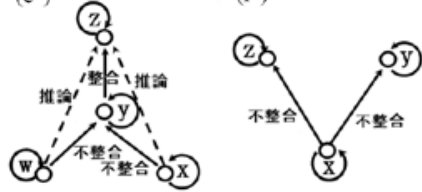

第 3 図 層序グラフの例. 露頭断面は第 2 図と同じものである. 各露頭断面の下に層序グラフを示す. 各頂点に反射律を意味するルー プが付いている．矢印は下位の単層から上位の単層に向く．(c) と (d) には推移的閉包を意味する弧が点線の矢印で示されている. 層序グラフは単層の新旧関係，すなわち単層の形成順序を示している．弧にはラベルとして接触関係の名称がつく．推移的閉包 により得られた破線の弧には一律「推論」という用語のラベルが付く. 
プと推移的閉包で生み出された関係を示す弧 $(w, z)$ と $(x, z)$ が追加されている。いずれの場合も推移的閉包で追加され た弧は破線の矢印で示されている。（f）では反射的性質を 示すループだけが追加されている。

反射的性質を示すループを無視したグラフで考えると， 半順序集合 $\left(V, U^{*}\right)$ に最大元と最小元が存在する場合, 出 次数が 0 の頂点が形成時期の最も新しい単層を表し，入次 数が 0 で頂点が形成時期の最も古い単層を表す。最小元か ら最大元までの道が層序になる。半順序集合 $\left(V, U^{*}\right)$ に最 大元あるいは最小元が存在しない場合には，形成時期が最 も新しいあるいは形成時期が最も古い単層が決まらないの で層序は確定できない. $\left(\mathrm{a}^{\prime}\right),\left(\mathrm{b}^{\prime}\right),\left(\mathrm{c}^{\prime}\right),\left(\mathrm{d}^{\prime}\right)$ のグラフは 最大元と最小元が存在する層序グラフであり，(e') は最小 元が存在しない層序グラフであり，(f) は最大元が存在し ない層序グラフである。

第 3 図 $\left(\mathrm{c}^{\prime}\right)$ では $(v, w, x, y, z)$ という $v-z$ 歩道が存在する. したがって，形成時期の古い下位の単層から新しいもの上 位に向かって, $v=v_{1}, w=v_{2}, x=v_{3}, y=v_{4}, z=v_{5}$ と番号を つけることができる。堆積順序は $(v, w, x, y, z)$ となる。 こ の堆積順序に単層間の接触関係を書き入れた

$P^{\prime}=(v$, 不整合, $w$, 整合, $x$, 整合, $y$, 不整合, $z)$

は層序である。

地層の逆転がない場合，地層累重の法則により，

$$
x R y \Rightarrow x U y
$$

という規則で空間的上下関係 $R$ を新旧関係 $U$ に変換して いるので，層序グラフは構造グラフに反射的性質を表す ループと推移的閉包により生み出された関係を表す弧が追 加されたものになる，逆にいえば，層序グラフからループ と推移的閉包による弧を省略した場合, 構造グラフと同じ 形になる，地層の逆転が存在する場合には，単層間の空間 的上下関係と新旧関係は逆になるので, 構造グラフと層序 グラフは同じ形にならない。

（b）ハッセ図による層序の表現

$(V, \leqq)$ を半順序集合とし， $x \leqq y$ でありかつ $x \neq y$ であ ることを $x<\mathrm{y}$ と書いたとする $x<y$ でありかつ $x<\mathrm{z}$ $<y$ となるような $\mathrm{z}$ が存在しないとき, $y$ は $x$ を覆うといい, そのような関係にある順序対 $(x, y)$ の集合

$$
C_{V}=\{(x, y) \mid x, y \in V \text { かつ } y \text { は } x \text { を覆う }\}
$$

を被覆集合という。すべての $(x, y) \in C_{V}$ に対して,$x$ が下 に $y$ が上になるように配置したグラフ $\left(V, C_{V}\right)$ をハッセ図と いう。 ハッセ図では $y$ が $x$ を被覆するとき, $x$ が下で $y$ が上 になるように頂点が配置されるので矢印は省略される。

第 4 図に層序グラフ $\left(V, U^{*}\right)$ に対するハッセ図 $\left(V, C_{V}\right)$ の例を示す。第 4 図 (a) は第 3 図 (d) の露頭断面と同じも のである。(a-1)が層序グラフ, (a-2)がそのハッセ図である. (a) の露頭断面では，被覆集合は次のようになる.

$$
C_{V}=\{(v, w),(w, x),(x, y),(y, z)\}
$$

単層の並び $P=(w, x, y, z)$ は全順序であり，ハッセ図は 分岐のない1本の線で表現される。第 4 図(b) は第 3 図 (e) と同じ露頭断面である。(b-1) が層序グラフ，(b-2) がその ハッセ図である。被覆集合は次のようになる。

$$
C_{V}=\{(w, y),(x, y),(y, \mathrm{z})\}
$$

この露頭断面では $w$ と $x$ の関係は不明である。このため, (b-2)に示すようにハッセ図は分岐のある図になる。

ハッセ図を使えば，順序関係を単純な図で表すことがで き，単層の形成順序を表現するのに適している．本論文で は，単層の形成順序と単層間の接触関係の両方が確定した ものを層序とよんでいる，ハッセ図の各弧に元の層序グラ フのラベルを追加してラベル付き有向グラフ $H=\left(V, C_{V}\right.$, $\left.\phi_{V}, \phi_{A}\right)$ として表現すると, 形成順序と接触関係の両方を 一つのグラフで表現できて, 層序を表すのに好都合である. ここで， $\phi_{A}$ は順序対 $(x, y) \in C_{V}$ に接触関係の名称の集合 $A=\{$ 整合, 不整合 $\}$ の 1 つの元を対応つける写像 $\phi_{A}: C_{V}$ $\rightarrow A$ であり，ハッセ図の各弧に構造グラフや層序グラフ におけるラベルと同じラベルを付ける働きをする，以下， このようなラベル付き有向グラフ $H=\left(V, C_{V}, \phi_{V}, \phi_{A}\right)$ を「ラ ベル付きハッセ図」という。

第 4 図 (a) の露頭断面では，各弧のラベルは次のように なる。

$$
\begin{aligned}
& \phi_{A}(v, w)=\text { 整合 } \\
& \phi_{A}(w, x)=\text { 不整合 } \\
& \phi_{A}(x, y)=\text { 整合 } \\
& \phi_{A}(y, z)=\text { 不整合 }
\end{aligned}
$$

これらのラベルを（a-2）のハッセ図に追加すると，（a-3）に 示すように形成順序と接触関係の両方が表示されたラベル 付きハッセ図となる。このグラフは (a-4) に示す柱状図を 表しており，(a-3) のグラフで地層の形成史を表現するこ とができる。

第 4 図（b) の露頭断面では，各弧のラベルは次のように なる。

$$
\begin{aligned}
& \phi_{A}(w, y)=\text { 不整合 } \\
& \phi_{A}(x, y)=\text { 不整合 } \\
& \phi_{A}(y, z)=\text { 整合 }
\end{aligned}
$$

これらのラベルを(b-2) のハッセ図に追加すると，(b-3) に示すラベル付きハッセ図となる。(b-3) のグラフで明ら かなように単層 $w$ と $x$ の関係が不明なので全順序ではな い.（b-4）はあえて柱状図の形に表してみたが，未完成で ある・

\section{（c）層序グラフの性質}

層序グラフは単層間の新旧関係を表示したラベル付き有 向グラフであり，頂点と弧はそれぞれ地層と地層間の新旧 関係を表している，複雑さを避けるために，層序グラフか ら推移的閉包により生ずる弧と反射律を意味するループを 除いて描画することもある。

層序グラフの性質に次のものがある.

（1） 2 層以上の単層からなる層序グラフの位数は 2 以上,

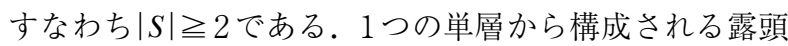

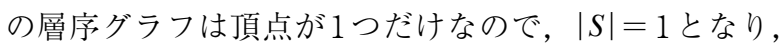



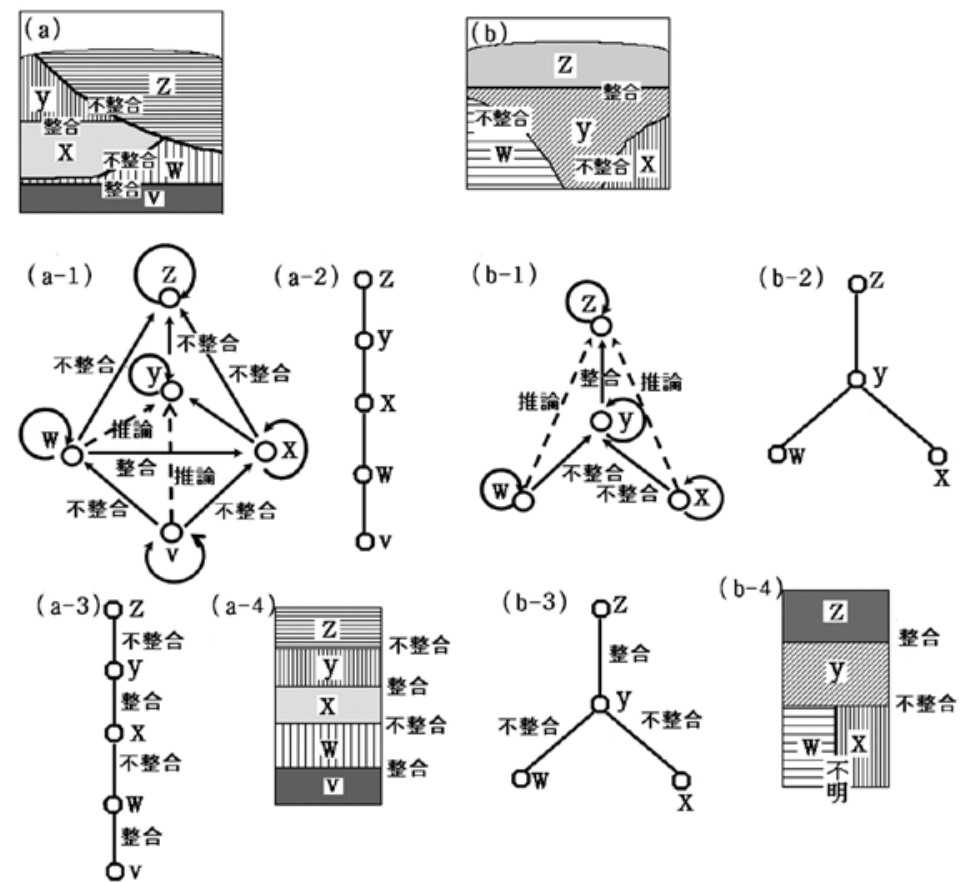

第 4 図ハッセ図とラベル付きハッセ図（a)の露頭断面は第 3 図 (d) の露頭断面と同じものである. (a-1) が層序グラフ，(a-2) がハッセ 図である. (a) の露頭断面に扔ける新旧関係は全順序であり,ハッセ図は分岐のない 1 本の線で表現される。(a-3) はラベル付きハッ セ図で，頂点間を結ぶ線に各頂点間の接触関係のラベルが付く．ラベル付きハッセ図は (a-4)の柱状図に対応している. (b) は第 3 図 (e) と同じ露頭断面である. (b-1) が層序グラフ，(b-2)がハッセ図である. (b) の露頭断面では $w$ と $x$ の関係は不明なのでハッセ 図は分岐のある図になる。(b-3) はラベル付きハッセ図であり，(b-4) はラベル付きハッセ図から描画された柱状図である.

構造グラフ(1)の性質も受け継いでいる.

(2) 層序グラフで2点が連結している場合は必ず片方向連 結であり，その弧は形成時期が古い地層から新しい地層 に向く.

（3）層序グラフに最大元と最小元が存在する場合, 入次数 が1の頂点が最下位の単層であり, 出次数が 1 の頂点が 最上位の単層である。第3図 (c) の例では最下位の単層 $v$ の入次数は反射的性質を意味するループの1であり, 最 上位の単層の $z$ は反射的性質を意味するループのだけの 出次数が1である. 入次数が 1 の頂点あるいは出次数が 1 の頂点は 1 つとは限らない。例えば，第 3 図 (e)の例で は出次数が 1 の頂点が 2 つり最下位の単層が決まらな い. $(\mathrm{f})$ の例では入次数が 1 の頂点が $2 つ$ あので, 最上 位の単層が決まらない。

（4）層序グラフでは多重弧が存在しない。弧は頂点すなわ ち地層間の接触関係を表していて，接触関係は 1 種類し かないからである。ただし，反射的かつ推移的閉包によ り生み出された弧は必ずしも接触関係を表していない.

\section{4. 層序グラフの演算による層序の構築}

\section{4-1. 露頭層序グラフの演算}

第 5 図 (a)の露頭断面は $x$ と $y$ の 2 つ単層が $w$ を覆つ ており, $z$ は $w, x, y$ の 3 つ地層を覆っている。単層 $x$ と $y$ の関係は不明である。露頭断面 (b)では, $y$ が $w$ と $x$ を不整合で覆い， $z$ は $y$ を整合で覆っている，単層 $w$ と $x$
の関係は不明である，露頭断面 (a) と (b) の層序グラフを それぞれ $\left(a^{\prime}\right)$ と $\left(b^{\prime}\right)$ に示す。この図では反射的性質を意 味するループを省略している。破線の矢印は推移的閉包の 操作により得られる弧である。( $\left.\mathrm{a}^{\prime}\right)$ の場合, $x$ と $y$ の関係 が不明なので $x U^{*} y$ と $y U^{*} x$ のどちらが成立するか判断でき ず，( $\left.\mathrm{b}^{\prime}\right)$ では $w U^{*} x$ と $x U^{*} w$ のどちらが成立するか判断で きない.いずれも 1 つの露頭のデー夕だけではすべての単 層の堆積順序を決定できない例である。このような場合， 調査を進めて, 別な露頭で見つけたデー夕を追加して堆積 順序を決定しょうとするのが常である。このような複数の 露頭で得られたデー夕に基づいて一定地域の層序を確定す る手続きを,複数の「露頭層序グラフ」を重㸚合わせて「地 域層序グラフ」を作成するという観点から考察する。

第 6 図 (a) に示す露頭 $\mathrm{A}$ から得られた層序グラフ $S_{A}=$ $\left(V_{A}, U_{A}^{*}\right)$ を $\left(\mathrm{a}^{\prime}\right)$ に示す。ただし，このグラフでは反射的 性質を表すループは省略している。この露頭では， $v_{2}$ と $v_{3}$ とは接触せず， $v_{2} U^{*} v_{3}$ あるいは $v_{3} U^{*} v_{2}$ のどちらが成立する か不明である。

周辺地域の露頭 B で第 6 図 (b) に示す露頭断面が存在 したとする。層序グラフ $S_{B}=\left(V_{B}, U_{B}^{*}\right)$ を $\left(\mathrm{b}^{\prime}\right)$ に示す。こ の露頭では $v_{2}$ と $v_{3}$ が不整合関係で接触しており，その新 旧関係は $v_{2} U^{*} v_{3}$ である。この露頭では単層 $v_{1}$ は露出して いないので， $v_{1}$ との関係についての情報は得られない。

露頭 $\mathrm{B}$ で得られた単層 $v_{2}$ と $v_{3}$ に関する情報を，露頭 $\mathrm{A}$ の層序グラフ $S_{A}$ に埋め込んだものを $\left(\mathrm{c}^{\prime}\right)$ に示す。このグ 
ラフから単層の形成順序は

$$
P_{A B}=\left(v_{1}, v_{2}, v_{3}, v_{4}\right)
$$

であることがわかる．頂点間を連結する弧を書き入れると

$$
P_{A B}=\left(v_{1}, v_{1} v_{2}, v_{2}, v_{2} v_{3}, v_{3}, v_{3} v_{4}, v_{4}\right)
$$

となる. 弧の位置に接触関係の名称を代入すると次のよう になる

$P_{A B}^{\prime}=\left(v_{1}\right.$, 不整合, $v_{2}$, 不整合, $v_{3}$, 不整合, $\left.v_{4}\right)$

このようにして，2つの露頭 $\mathrm{A}, \mathrm{B}$ の層序グラフを組み 合わせることによって 4 つの単層 $v_{1}, v_{2}, v_{3}, v_{4}$ の層序を確定 することができる。

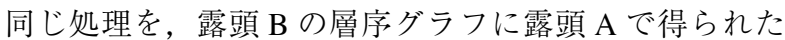
情報を追加するという観点から検討する。

露頭断面 B でみられる単層の堆積順序 $P_{B}$ は

$$
P_{B}=\left(v_{2}, v_{3}, v_{4}\right)
$$

であり，各頂点間を連結する弧を書き入れる

$$
P_{B}=\left(v_{2}, v_{2} v_{3}, v_{3}, v_{3} v_{4}, v_{4}\right)
$$

となる. 弧の位置に接触関係の名称を代入すると次のよう になる。

$P_{B}^{\prime}=\left(v_{2}\right.$, 不整合, $v_{3}$, 不整合, $\left.v_{4}\right)$

この $P_{B}^{\prime}$ は堆積順序と単層間の接触関係すなわち層序を 表している.

露頭 $\mathrm{B}$ の層序グラフに頂点 $v_{1}$ を追加し，露頭 $\mathrm{A}$ で得ら れた関係 $v_{1} U^{*} v_{2} ， v_{1} U^{*} v_{3}, v_{1} U^{*} v_{4}$ とそれぞれに接触関係を埋 め込むと，(c) のような層序グラフがえられる。その結果， $v_{2}$ の下位の単層が $v_{1}$ であることがわかる．この結果を $P^{\prime}{ }_{B}$ に組み込むと，次の層序 $P^{\prime}{ }_{A B}$ が得られる。

$P_{A B}^{\prime}=\left(v_{1}\right.$, 不整合, $v_{2}$, 不整合, $v_{3}$, 不整合, $\left.v_{4}\right)$

このようにして露頭 $\mathrm{A}$ の層序グラフ $S_{A}=\left(V_{A}, U_{A}^{*}\right)$ と露 頭 B の層序グラフ $S_{B}=\left(V_{B}, U_{B}^{*}\right)$ から新しい層序グラフ $S_{L}$ $=\left(V_{L}, U_{L}^{*}\right)$ を作成することができる. (a)

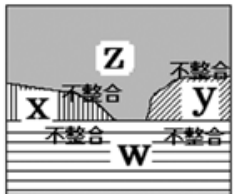

$\left(a^{\prime}\right)$

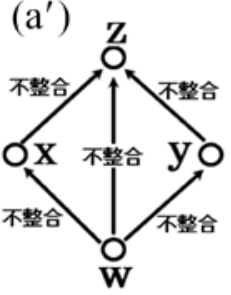

(b)

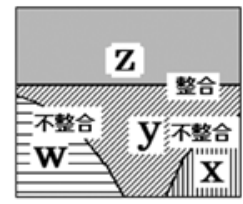

$\left(b^{\prime}\right)$

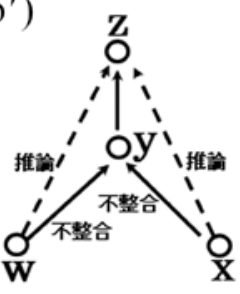

第 5 図 層序が確定できない露頭断面と層序グラフ. 露頭断面 (a) と (b) は 4 つの単層 $w, x, y, z$ から構成 されている.それぞれのグラフを $\left(\mathrm{a}^{\prime}\right)$ と ( $\left.\mathrm{b}^{\prime}\right)$ に示す. $(\mathrm{a})$ では $x$ と $y$ の関係が，(b) では $w$ と $x$ の関係がそれぞ れ不明である。推移的閉包による関係を破線の矢印 で示している。( $\left(\mathrm{a}^{\prime}\right)$ では $x$ と $y$ の間の弧が，( $\left.\mathrm{b}^{\prime}\right)$ では $w$ と $x$ の間の弧が存在しない.
一般に 2 つの層序グラフ $S_{A}, S_{B}$ が与えられたとき,

- $S_{A}$ に $S_{B}$ の頂点を追加する

$\cdot S_{A}$ に $S_{B}$ の弧 (ラベル付き) を追加する

・推移的閉包で生み出されるを追加する

という手続きにより，新しい層序グラフを作成する処理を

$S_{A}$ と $S_{B}$ の重ね合わせといい，それを $S_{A}$ と $S_{B}$ の演算とみ なして

$$
S_{L}=S_{A} ※ S_{B}
$$

と書く.

\section{4-2．露頭層序グラフの演算による地域層序グラフの確定}

ある地域に存在するすべての単層の堆積順序と単層間の 接触関係が確定したとき，それを地域層序という。露頭に おける単層の積み重なり（露頭構造）を観察して，単層の 形成順序と接触関係を確定したものが露頭層序である．数 多くの露頭で得られた露頭層序を統合することにより，地 域全体の地域層序を確定することができる。この露頭層序 から地域層序を導く地質学的処理は層序グラフの重ね合わ せという演算で表現できる。

いま，ある地域に分布する単層の集合を $V_{L}$ とする， $n$ 地 点の露頭に露出している単層の集合を $V_{i}(i=1, \cdots, n)$ とし, 各 $V_{i}$ は $V_{L}$ の部分集合であるとする。このとき，各露頭で の観察により得られた露頭層序グラフを $S_{i}=\left(V_{i}, U_{i}^{*}\right)$ とす ると，これらのグラフの重ね合わせにより地域層序グラフ $S_{L}=\left(\mathrm{V}_{L}, U_{L}^{*}\right)$ を求めることができる。この演算は $S_{L}=S_{1} ※ S_{2} ※ \cdots \circledast S_{n}$

と書ける。

第 7 図は演算の例である。第 7 図 (a) の露頭断面が存在 したとする，単層 $v_{1}$ と $v_{5}$ の関係と $v_{1}$ と $v_{2}$ の関係は不整合 であることが観察できたが， $v_{2}$ と $v_{5}$ の接触関係は不明で
露頭A

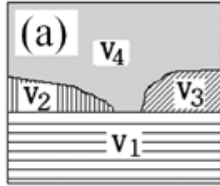

$\left(a^{\prime}\right)$

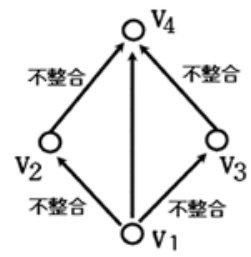

露頭B

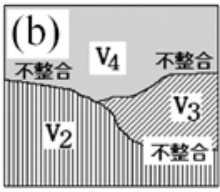

$\left(b^{\prime}\right)$

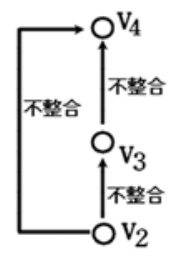

(c) $S_{A} \circledast S_{B}$

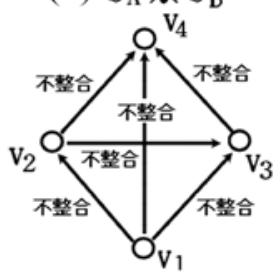

第 6 図 不明な関係の確定. 露頭断面 (a) は第 5 図 (a) と同じものであり, (a') は層序グラフである. 層序グラフでは反射律を示すループは

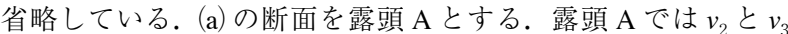
の関係が不明である。近隣の露頭 $\mathrm{B}$ では $v_{2}$ と $v_{3}$ の関係が $v_{2} U^{*} v_{3}$ である．露頭 $\mathrm{B}$ の層序グラフを $\left(\mathrm{b}^{\prime}\right)$ に示す。露頭 $\mathrm{A}$ の層序グラ フと露頭 $\mathrm{B}$ の層序グラフの演算から， $\left(v_{1}, v_{2}, v_{3}, v_{4}\right)$ という形成順 序が求まる（c) がこの演算により求まった層序グラフである。 
ある．露頭 $(\mathrm{a})$ の層序グラフ $S_{A}$ を $\left(\mathrm{a}^{\prime}\right)$ に示す．層序を確 定するには，単層 $v_{2}$ と $v_{5}$ の関係を調べる必要がある。近 隣に存在する露頭 (b) で図のような露頭断面が得られたと する。 $\left(\mathrm{b}^{\prime}\right)$ がその層序グラフ $S_{B}$ であり, 全順序となって いる. 露頭でみられる単層の堆積順序は $\left(v_{2}, v_{3}, v_{4}\right)$ である. 露頭 $(\mathrm{a})$ の層序グラフ $S_{A}$ と露頭 $(\mathrm{b})$ の層序グラフ $S_{B}$ の演 算 $S_{A} ※ S_{B}$ により, 新しい層序グラフが得られる。この層 序グラフを $(\mathrm{d})$ に示す。この演算結果においても，単層 $v_{5}$ と単層 $v_{2}, v_{3}, v_{4}$ との関係が不明である.さらに, 別の露頭 (c) で露頭断面が得られたとする. 露頭 (c) の層序グラフ $S_{C}$ を $\left(\mathrm{c}^{\prime}\right)$ に示す。この露頭で $v_{4}$ と $v_{5}$ の関係が観察できる. $S_{A} ※ S_{B}$ と $S_{C}$ の演算すなわち演算 $S_{A} ※ S_{B} ※ S_{C}$ から得られ た層序グラフを $(\mathrm{e})$ に示す。

以上のように，この地域に存在するすべての単層の集合 $V_{L}=\left\{v_{1}, v_{2}, v_{3}, v_{4}, v_{5}\right\}$ に関する地域層序グラフ $S_{L}$ は

$$
S_{L}=S_{A} ※ S_{B} ※ S_{C}
$$

という演算で求められる。 この地域層序グラフをラベル付 きハッセ図で示すと（f)のようになる，全順序であり，地 域層序は確定し

$\left(v_{1}\right.$ ，不整合， $v_{2}$, 整合, $v_{3}$, 整合, $v_{4}$, 不整合, $\left.v_{5}\right)$ である。

第 7 図の例では 3 か所の露頭層序の演算で地域層序が確 定したが，新旧関係が全順序にならない場合は，さらに近 隣の露頭層序の情報を追加していく必要がある.

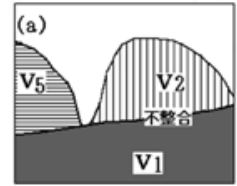

(a )

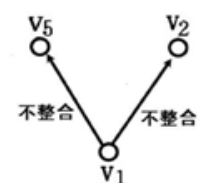

(d)

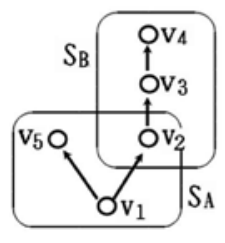

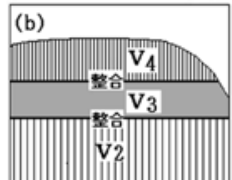

(b')

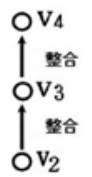

(e)

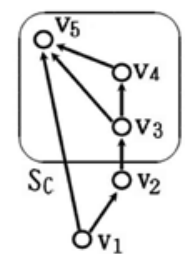

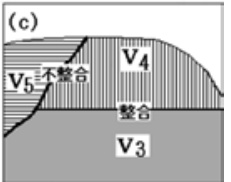

(c)

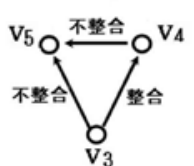

(f)

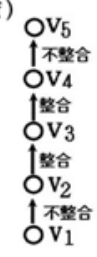

第 7 図 複数の露頭層序から地域層序を求める方法. 露頭 (a), (b), (c) の層序グラフをそれぞれ ( $\left.\mathrm{a}^{\prime}\right),\left(\mathrm{b}^{\prime}\right),\left(\mathrm{c}^{\prime}\right)$ に示す。露頭 (a) の層序グラフ $S_{A}$ と露頭 (b) の層序グラフ $S_{B}$ の演算 $S_{A} ※ S_{B}$ から得られる層序グラフを (d) に示す。露頭 (c) の層序グラ フ $S_{C}$ を加えた演算 $S_{A} ※ S_{B} ※ S_{C}$ から得られた層序グラフ を(e)に示す。（e）のグラフを整理したラベル付きハッセ図 が(f)である。

\section{4-3. 上位の地層単元の層序}

第 5 図の露頭断面 (a) と (b) のどちらも， $V$ 上の新旧関 係 $U^{*}$ は全順序ではない.このような場合, 全順序になるよ
うに，各単層を上位の地層単元にまとめることがある.

第 8 図(a)は第 5 図(a)と同じ露頭断面であるが，第 8 図(b) は

$$
L_{1}=\sigma\left(v_{1}\right), L_{2}=\sigma\left(v_{2}\right)=\sigma\left(v_{3}\right), L_{3}=\sigma\left(v_{4}\right)
$$

という $V=\left\{v_{1}, v_{2}, v_{3}, v_{4}\right\}$ から $V^{\prime}=\left\{L_{1}, L_{2}, L_{3}\right\}$ 一の写像 $\sigma: V \rightarrow V^{\prime}$ にしたがって，各単層を上位の層序単位に再区分したもの である。第 8 図 $\left(\mathrm{b}^{\prime}\right)$ は反射的性質を意味するループを省 略した層序グラフである。この場合，比較が不可能である 単層 $v_{2}$ と $v_{3}$ が，上位の単元では同一の単元 $L_{2}$ となり，3 つの頂点間に $L_{1} U^{*} L_{2}, L_{1} U^{*} L_{3}, L_{2} U^{*} L_{3}$ が成立し， $V^{\prime}=\left\{L_{1}\right.$, $\left.L_{2}, L_{3}\right\}$ 上の新旧関係 $U^{*}$ は全順序となる。

露頭層序グラフの重ね合わせにより地域層序グラフを求 めるにあたって，異なる河川系の堆積物で互いに接触して いない場合のように，新旧関係が確定できない単層の組み 合わせが存在することがある。そのような場合，第 8 図の 例のように，写像 $\sigma: V \rightarrow V^{\prime}$ により上位の地層単元にまと めると, $V^{\prime}$ 上の新旧関係 $U^{*}$ が全順序になることがある（河 西, 2006; Kasai, 2009).しかしながら，どのような写像 $\sigma: V \rightarrow V^{\prime}$ を設定するのがよいのか，あるいは上位の地層 単元間の接触関係はどのように定めるのがいいのかなど検 討すべき諸問題があり, 今後の課題として残す.
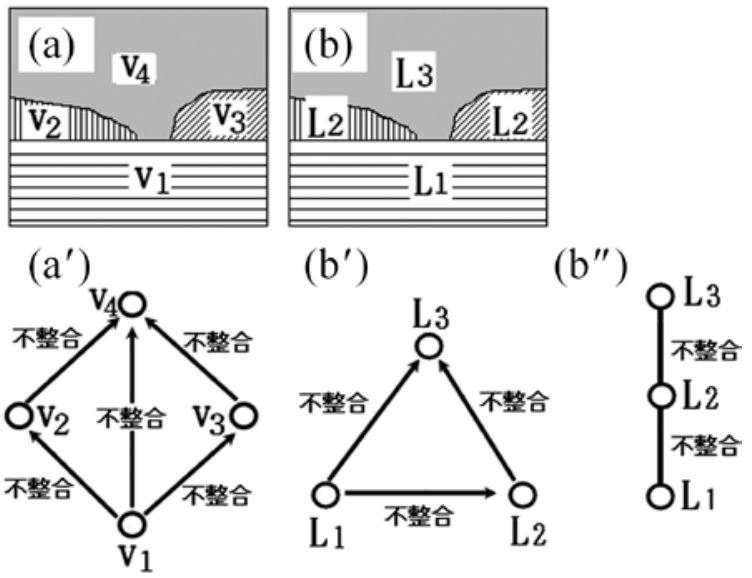

第 8 図上位の層序単元にまとめて層序を確定する方法. 露頭断 面 (a) は第 5 図 (a) と同じもので，(a') は層序グラフである. ただし，反射律を示すループは省略している．単層単位で は全順序ではない. (b) は写像 $L_{1}=\sigma\left(v_{1}\right), L_{2}=\sigma\left(v_{2}\right)=\sigma\left(v_{3}\right)$, $L_{3}=\sigma\left(v_{4}\right)$ で単層を上位の層序単元にまとめた例であり, $\left(\mathrm{b}^{\prime}\right)$ にその層序グラフを示す。この場合，新旧関係は全順序と なる. ( $\left.\mathrm{b}^{\prime}\right)$ の層序グラフをラベル付きハッセ図で示したも のが $\left(\mathrm{b}^{\prime \prime}\right)$ である.

\section{5. あとがき}

地層の逆転が存在せず，断層による地層の切断や火成岩 の貫入もない地質構造の層序と露頭構造の数学的表現につ いて検討した。層序を地層単元の集合と，その集合上の順 序で表現した。この順序には全順序でない場合と全順序の 場合がある。露頭構造は単層間の空間的位置関係を二項関 係 $R$ を使用してグラフで表現したもので，このグラフを 構造グラフとよぶ。これは，河西 (2003) の層序グラフを 
Kasai (2009) の構造グラフに名称を統一したものである. これに対して層序は単層の堆積順序を表すものなので，単 層の形成順序 (新旧関係) を意味する二項関係 $v_{i} U^{*} v_{j}$ を使 用して表現した。 $U^{*}$ は上下関係を意味する二項関係 $U$ の 反射的かつ推移的閉包である。層序は二項関係 $U^{*}$ で表現 される。露頭で観察される層序を表す $U^{*}$ は半順序であり， 必ずしも全順序になるとは限らない.

複数の露頭で観察される構造からある範囲の地域の層序 を組み立てることは露頭層序グラフの演算として表現でき る、今後は，断層や貫入のある地質構造についても検討す る必要がある。

大阪市立大学名誉教授塩野清治氏と近畿職業能力開発大 学校の山口久美子氏には，本論文をまとめるに当って貴重 な助言をいただいたことをここに感謝します。

\section{文 献}

Bondy, J. A. and Murty, U. S. R. (2008) Graph Theory. Springer, pp.7981.

河西秀夫 (2003) 個人用露頭データベースの設計について (2)一層 序の表現方法について一. 情報地質, vol.14, no.3, pp.249258.

河西秀夫 (2005) 個人用露頭データベースの設計について (3)一層 序の表現方法の改善について一. 情報地質, vol.16, no.2, pp.57-68.

河西秀夫 (2006) 個人用露頭データベースの設計について (4)一基 盤，被覆層，互層の理論的背景一. 情報地質，vol.17, no.1, pp.13-27.

Kasai, H. (2009) Design of geological exposure database -Structure graph: Mathematical model of geological structure of outcrops and regions based on graph theory-. Geoinformatics, vol.20, no.1, pp.17-29.

恵羅 博・土屋守正 (2010) 増補改訂版グラフ理論. 産業図書, pp.12. 塩野清治・弘海原 清 (1991) 論理地質学的にみた地層累重の法則 の論理構造. 情報地質, vol.2, no.1, pp.9-22.

塩野清治 (1997) テーブルの上に重ねたカードの公理 : 化石を含む 地層の論理モデル。情報地質, vol.8, no.4, pp.257-267.

Wilson, R. J. (1996) Introduction to Graph Theory, Fifth edition. Longman, pp.14-27. 
要 旨

\section{グラフ理論による露頭構造と層序の数学的表現}

河西 秀夫

露頭データベースの作成には層序と露頭構造の数学的表現が必要である. 露頭構造と層序の数学的表現方法とし てグラフ理論と二項関係を使用した構造グラフと層序グラフを提案し, 両者の理論的背景を検討した。地層の逆転 ががなく，断層による切断や火成岩の貫入もない地層群だけで構成される地質構造を対象とした，単層 $x$ が空間的 に $y$ の下側にあるという単層間の空間的位置関係を示す二項関係 $x R y$ を使用して露頭構造を表現すると, この関係 はラベル付き有向グラフで表現できる。このグラフ $G=(V, R)$ を構造グラフとよぶ. $V$ は露頭を構成する単層の集 合である，層序は単層の堆積順序を表すものなので, 単層の形成順序を意味する二項関係 $x U^{*} y$ を使用して表現した. $U^{*}$ は空間的な上下関係を意味する二項関係 $x R y$ の反射的かつ推移的閉包であり,$S=\left(V, U^{*}\right)$ で定義される有向グラ フを層序グラフとよぶ，層序は二項関係 $v_{i} U^{*} v_{j}$ で表現される。この手法により，露頭構造と層序の違いが数学的に表 現できる. 露頭で観察される新旧関係は半順序であり, 必ずしも全順序になるとは限らない. 複数の露頭で観察さ れる構造からある範囲の地域の層序を組み立てることは露頭層序グラフの演算を意味する.

キーワード：グラフ理論，構造グラフ，有向グラフ，層序，露頭 